\title{
Characterization of a Human Hematopoietic Progenitor Cell Capable of Forming Blast Cell Containing Colonies In Vitro
}

\author{
John Brandt, Nancy Baird, Li Lu, Edward Srour, and Ronald Hoffman \\ Division of Hematology/Oncology and Indiana Elks Cancer Research Center, Indiana University School of Medicine, Indianapolis, \\ Indiana 46223
}

\begin{abstract}
A hematopoietic cell (CFU-B1) capable of producing blast cell containing colonies in vitro was detected using a semisolid culture system. The CFU-B1 has the capacity for self-renewal and commitment to a number of hematopoietic lineages. Monoclonal antibody to the human progenitor cell antigen-1 (HPCA-1) and a monoclonal antibody against the major histocompatibility class II antigen (HLA-DR) were used with fluorescence activated cell sorting to phenotype the CFU-B1. The CFU-B1 was found to express My10 but not HLA-DR antigen; experiments using complement-dependent cytotoxicity to eliminate DR positive cells confirmed this finding. Pretreatment of marrow cells with two chemotherapeutic agents, 5-fluorouracil and 4-hydroperoxycyclophosphamide facilitated detection of CFU-B1 derived colonies, while diminishing or totally inhibiting colony formation by other hematopoietic progenitor cells. CFU-B1-derived colony formation was dependent upon the addition of exogenous hematopoietic growth factors. Media conditioned either by the human bladder carcinoma cell line 5637 or lectin stimulated leukocytes, as well as recombinant granulocyte-macrophage colony stimulating factor, interleukin 3 or interleukin $1 \alpha$ promoted blast cell colony formation. By contrast, neither recombinant erythropoietin, recombinant interleukin 4, purified macrophage colony stimulating factor or recombinant granulocyte colony-stimulating factor alone promoted blast cell colony formation.
\end{abstract}

\section{Introduction}

Primitive hematopoietic progenitor cells capable in vitro of producing colonies composed of blast cells (CFU-B1) ${ }^{1}$ have

Address reprint requests to Dr. Hoffman, Division of Hematology/Oncology, Clinical Building, Room 379, 541 Clinical Drive, Indianapolis, IN 46223.

Received for publication 12 February 1987 and in revised form 23 March 1988.

1. Abbreviations used in this paper: BFU-E, erythroid burst forming unit; CFU-B1, blast cell colony forming unit; CFU-GM, granulocytemonocyte colony forming unit; CFU-GEMM, granulocyte, erythroid, monocyte, megakaryocyte colony forming unit; CFU-MK, megakaryocyte colony forming unit; CM, conditioned media; CSA, colony stimulating activity; CSF, colony stimulating factor; CSF-1 (M-CSF), macrophage colony stimulating factor; Epo, erythropoietin; FBS, fetal bovine serum; 5-FU, 5 fluorouracil; G-CSF, granulocyte colony stimulating factor; GM-CSF, granulocyte-macrophage colony stimulating factor; $\mathrm{H}-1$, hemopoietin-1; 4-HC, 4 hydroperoxycyclophosphamide; IL- $1 \alpha$, interleukin $1 \alpha$; IL-3, interleukin 3 or multi-colony stimulating

J. Clin. Invest.

(C) The American Society for Clinical Investigation, Inc.

0021-9738/88/09/1017/11 \$2.00

Volume 82, September 1988, 1017-1027 been detected in murine bone marrow, human umbilical cord blood and, most recently, in normal human marrow (1-6). These cells possess many of the features of stem cells in that they are capable of self-renewal and also commitment to a number of hematopoietic lineages (1-6).

Human marrow is composed of heterogeneous populations of hematopoietic precursor and progenitor cells. A variety of in vitro clonal assay systems have been utilized to detect progenitor cells in the presence of various hematopoietic growth factors (7-9). Each of these cells have been shown to produce colonies composed of differentiated cellular elements with limited self-renewal capacity (10-12). Since the frequency of various hematopoietic progenitor cells appears to be directly related to the degree of their cellular differentiation, one would hypothesize that the frequency in normal bone marrow of CFU-B1 is extremely low. To facilitate the enrichment of CFU-B1, a number of physical and immunological characteristics of these cells could be utilized (13-28). Another means of obtaining enriched populations of CFU-B1 might be to pharmacologically purge the marrow of more differentiated elements by in vitro exposure to chemotherapeutic agents (29, 30). Van Zant has previously shown that in vitro exposure of murine marrow cells to 5-fluorouracil (5-FU) results in the direct, rapid kill of more differentiated progenitor cells and the selective sparing of primitive pluripotent hematopoietic stem cells (30). 5-FU does not require in vivo metabolism for this effect to occur. We used monoclonal antibody labeling and fluorescence activated sorting or counterflow centrifugal elutriation and in vitro chemoselection to obtain a cell population with which we have developed an assay for the human CFU-B1. These studies provide additional information on the chemosensitivity, immunological phenotype and growth factor dependence of the human CFU-B1. These data suggest that the CFU-B1 is an extremely rare, quiescent cell present in human bone marrow. Data presented here also demonstrate the ability of the CFU-B1 to form blast cell containing colonies in vitro in the presence of a number of hematopoietic regulatory molecules.

\section{Methods}

Cell separation techniques. Bone marrow aspirates were obtained from the posterior iliac crest of hematologically normal volunteers after informed consent was obtained according to guidelines established by the Human Investigation Committee of the Indiana University School of Medicine. The samples were immediately diluted 1:1 with Iscove's modified Dulbecco's medium (IMDM, Gibco Laboratories, Grand Island, NY) containing $20 \mathrm{U} / \mathrm{ml}$ sodium heparin. This mixture was

factor; NAL, nonadherent low density cells; NALT $^{-}$, nonadherent low density $\mathrm{T}$ cell depleted marrow cells; $\mathrm{LD}$, low density marrow cells; PHA-LCM, phytohemagglutinin stimulated leukocyte conditioned medium; PE, phycoerythrin; TR, Texas Red. 
passed through a $150-\mu \mathrm{M}$ screen and layered over an equal volume of Ficoll-Paque (specific gravity $1.077 \mathrm{~g} / \mathrm{cm}^{3}$; Pharmacia Fine Chemicals, Piscataway, NJ). Density centrifugation was performed using a centrifuge (model TJ-6R; Beckman Instruments, Inc., Palo Alto, CA) at 500 $g$ for $25 \mathrm{~min}$ at $4^{\circ} \mathrm{C}$ and the interface layer of low density mononuclear cells (LD) was collected, washed, and resuspended in PBS-EDTA (PBS, pH 7.4 containing 5\% FBS, vol/vol 0.01\% ETDA, wt/vol, and $1.0 \mathrm{~g}$ /liter D-glucose). The cells were then injected into an elutriator system with a standard separation chamber (Beckman Instruments, Inc.) that had previously been sterilized with a $70 \%$ ethanol solution, washed with sterile distilled water, and primed with PBS-EDTA. Rotor speed and temperature were maintained at $1,950 \mathrm{rpm}$ and $10^{\circ} \mathrm{C}$ throughout the elutriation. After loading, $200 \mathrm{ml}$ of effluent was collected at a flow rate of $10 \mathrm{ml} / \mathrm{min}$ and $100 \mathrm{ml}$ were collected at flow rates of $11,12,14,16,18,20,22,24,28$, and $32 \mathrm{ml} / \mathrm{min}$, after which the rotor was stopped and the final fraction flushed from the separation chamber (31).

Treatment with chemotherapeutic agents. 5-FU (Sigma Chemical Co., St. Louis, MO) and 4 hydroperoxycyclophosphamide (4-HC, Gift of Dr. O. Michael Colvin, the Johns Hopkins School of Medicine, Baltimore, MD) were dissolved in IMDM and sterilized by $0.22 \mu \mathrm{m}$ filtration (Millipore Corp., Bedford, MA). Elutriated fractions were washed in IMDM and incubated for 24-72 $\mathrm{h}$ at a concentration of 1 $\times 10^{6}$ cells $/ \mathrm{ml}$ at $37^{\circ} \mathrm{C}$ in $100 \%$ humidified air with $5 \% \mathrm{CO}_{2}$ in IMDM containing $10 \%$ FBS and varying concentrations of the above drugs. After appropriate incubation periods, the cells were washed and assayed for ability to form hematopoietic colonies.

Preparation of 5637 CM. Human bladder carcinoma cell line 5637 was grown to semi-confluence in cell culture flasks (Corning Glass Works, Corning, NY) in RPMI 1640 with $1 \%$ FBS at $37^{\circ} \mathrm{C}$ with $5 \%$ $\mathrm{CO}_{2}$ in $100 \%$ humidified air. The supernatant was discarded and new medium incubated over the cells for $7 \mathrm{~d}$. Supernatant was then collected, spun at $500 \mathrm{~g}$ to remove cells, and stored at $-20^{\circ} \mathrm{C}$.

Preparation of phytohemagglutinin stimulated leukocyte conditioned medium. Peripheral blood collected from hematologically normal volunteers was diluted 1:1 with IMDM containing $20 \mathrm{U} / \mathrm{ml}$ sodium heparin and layered over an equal volume of Ficoll-Paque. Density centrifugation was performed as previously described and the interface layer of low density mononuclear cells collected, washed, and suspended in IMDM with $10 \%$ FBS at $1 \times 10^{6} \mathrm{cells} / \mathrm{ml} .1 \% \mathrm{vol} / \mathrm{vol}$ phytohemagglutinin (Wellcome Diagnostics, Dartford, England) was added and the cell suspension incubated for $7 \mathrm{~d}$ at $37^{\circ} \mathrm{C}$ with $5 \% \mathrm{CO}_{2}$ in $100 \%$ humidified air. The cell suspension was then pelleted at $500 \mathrm{~g}$ and the supernatant stored at $-20^{\circ} \mathrm{C}$.

Source of growth factors. Lyophilized, partially purified $(57 \mathrm{U} / \mathrm{mg}$ protein) human urinary erythropoietin (Epo) (Toyobo Co., Ltd., Osaka, Japan) was reconstituted in IMDM and stored at $20 \mathrm{U} / \mathrm{ml}$ at $-20^{\circ} \mathrm{C}$. Purified human macrophage colony stimulating factor (CSF-1) with a specific activity of $10^{8} \mathrm{U} / \mathrm{mg}$ protein was a gift of Dr. Peter Ralph of the Cetus Corporation, Emeryville, CA. Recombinant human granulocyte colony-stimulating factor (G-CSF) with a specific activity of $1 \times 10^{8} \mathrm{U} / \mathrm{mg}$ and recombinant human erythropoietin (rEpo, 70,000-80,000 $\mathrm{U} / \mathrm{mg}$ protein $>95 \%$ purity by SDS-PAGE and HPLC) were purchased from AmGen Biologicals, Thousand Oaks, CA, while the recombinant human interleukin 3 (rIL-3, specific activity $10^{8} \mathrm{CFU} / \mathrm{mg}$ protein), interleukin 4 (rIL-4, specific activity $10^{8}$ $\mathrm{CFU} / \mathrm{mg}$ protein) and human granulocyte-macrophage colony-stimulating factor (rGM-CSF, specific activity greater than $5 \times 10^{7} \mathrm{CFU}$ $\mathrm{c} / \mathrm{mg}$ protein) were purchased from the Genzyme Corp., Boston, MA. The recombinant human interleukin $1 \alpha$ (rIL- $1 \alpha$ ) was obtained from two sources. One preparation of rIL- $1 \alpha$ was a gift of Dr. Peter LoMedico, Hoffman-LaRoche, Nutley, $\mathrm{NJ}$, and had a specific activity of $10^{9}$ $\mathrm{U} / \mathrm{mg}$ protein, while the second source of $\mathrm{rLL}-1 \alpha$ was the Genzyme Corp., Boston, MA, and had a specific activity of $10^{8} \mathrm{U} / \mathrm{mg}$ protein.

Hematopoietic progenitor cell assays. $1 \times 10^{5}$ drug-treated or control cells were suspended in 35-mm plastic tissue culture dishes (Costar, Cambridge, MA) containing a 1-ml mixture of IMDM, $1.1 \%$ methylcellulose, $30 \%$ FBS, $5 \times 10^{-5} \mathrm{M}$ 2-mercaptoethanol, 1 U Epo, and 10\% PHA-LCM (32). The culture dishes were incubated at $37^{\circ} \mathrm{C}$ in a $100 \%$ humidified atmosphere of $5 \% \mathrm{CO}_{2}$ in air. Granulocyte-macrophage derived colonies (CFU-GM), erythropoietic bursts (BFU-E) and multiple lineage colonies (CFU-GEMM) were enumerated after 14 and $21 \mathrm{~d}$ using an inverted light microscope using standard criteria for their identification $(12,32)$.

$C F U-B 1$ assay. $1 \times 10^{5}$ drug-treated or control cells were suspended in $35 \mathrm{~mm}$ plastic tissue culture dishes containing a 1-ml mixture of IMDM, $1.1 \%$ methylcellulose, $30 \%$ FBS, $5 \times 10^{-5} \mathrm{M} 2$-mercaptoethanol, $1 \mathrm{U}$ of Epo, and $10 \% 5637 \mathrm{CM}$. The culture dishes were incubated at $37^{\circ} \mathrm{C}$ in a $100 \%$ humidified atmosphere of $5 \% \mathrm{CO}_{2}$ in air and at $21 \mathrm{~d}$ scanned using an inverted light microscope to detect blast cell colonies.

Colonies composed of undifferentiated cellular elements were plucked from the methylcellulose under direct microscopic visualization using sterile 100- $\mu$ l glass micropipettes (Drummond Scientific Co., Broomall, PA) and suspended in $200 \mu \mathrm{IMDM}$ in sterile $1.5-\mathrm{ml}$ microcentrifuge tubes (Tekmar Co., Cincinnati, OH). $100 \mu \mathrm{l}$ of this volume was suspended in a 350- $\mu$ l mixture of IMDM with $1.1 \%$ methylcellulose, 30\% FBS, $5 \times 10^{-5} \mathrm{M}$ 2-mercaptoethanol, $0.35 \mathrm{U}$ Epo, and $10 \% 5637$ CM or PHA-LCM in 24-well tissue culture plates (Corning Glass Works). The remaining $100 \mu \mathrm{l}$ was transferred to slides on a Cytospin 2 (Shandon Southern Instruments, Inc., Sewickly, PA) at 750 rpm for 5 min for Wright Giemsa staining and microscopic examination. Culture plates were incubated at $37^{\circ} \mathrm{C}$ in $100 \%$ humidified air with $5 \% \mathrm{CO}_{2}$ for $14 \mathrm{~d}$, after which they were plucked from the methylcellulose, resuspended in $100 \mu \mathrm{l}$ PBS, and transferred to slides for staining and examination.

\section{Separation of cells by cell sorting}

The LD marrow cells were depleted of adherent cells by methods previously described (33). Nonadherent low density (NAL) cells routinely contained less than $3 \%$ esterase positive cells as determined by $\alpha$-naphthyl acetate esterase staining. To further enrich for progenitors, marrow NAL cells were separated into $E$ rosette positive $\left(E^{+}\right)$and negative $\left(E^{-}\right)$populations (33). Interphase cells constituted the NAL, $T$ lymphocyte depleted (NALT ${ }^{-}$) fraction. The $\mathrm{E}^{+}$fraction contained $>98 \% \mathrm{~T}$ cells and the $\mathrm{NALT}^{-}$fractions contained $\leq 3 \% \mathrm{~T}$ cells.

Labeling cells. For two-color cell sorting, antibodies of different subclasses were selected. The mouse anti-My10 (HPCA-1) and the mouse anti-MHC class II (HLA-DR, clone L243, conjugated with phycoerythrin, $\mathrm{PE}$ ) are of the $\mathrm{IgG}_{1}$ and $\mathrm{IgG}_{2 \mathrm{a}}$ subclass, respectively, and were purchased from Becton-Dickinson Immunocytometry Systems, Inc., Sunnyvale, CA. All the monoclonal antibodies were dialyzed to remove sodium azide and were titrated and analyzed by flow cytometry for saturable binding, and used at saturating levels. Cells were incubated in sequence with My10, then with a biotinylated goat anti mouse IgG second antibody (Vector Laboratories, Inc., Burlingame, CA) and TR Avidin D (Vector Laboratories, Inc.) or FITC-conjugated goat anti mouse IgG $_{1}$ (Southern Biotechnology, Birmingham, AL). Mouse serum, and finally PE-conjugated mouse anti-HLA-DR monoclonal antibody was added. Briefly, marrow cells were treated with $5 \mu 1$ of $\mathrm{My} 10 / 10^{6}$ cells for $20 \mathrm{~min}$ at $4^{\circ} \mathrm{C}$, and washed twice. The cells were then treated with either FITC-conjugated goat anti-mouse $\operatorname{IgG}_{1}(2.5$ $\mu \mathrm{l} / 10^{6}$ cells) or biotinylated goat anti-mouse $\mathrm{IgG}_{1}\left(2 \mu \mathrm{l} / 10^{6}\right.$ cells for 20 min), washed twice, and subsequently incubated with TR Avidin D for 20 min and washed twice. The cells were next incubated with mouse serum in order to block any unbound active sites on the biotin-conjugated goat anti-mouse $\operatorname{IgG}_{1}$ second step antibody. Finally, the cells were treated with PE-conjugated monoclonal antibody HLA-DR (DR/PE, Becton-Dickinson), $\left(20 / 10^{6}\right)$ for $20 \mathrm{~min}$ and washed three times. Negative control stains for My10/TR, My10/FITC and DR/PE were included in each experiment. Either biotin conjugated or nonbiotin-conjugated $\mathrm{IgG}_{1}$ myeloma protein was added to cells followed by the TR or FITC conjugated second step antibody. Nonspecific uptake of the $\mathrm{IgG}_{1}$ protein was minimal $(<1 \%$ positive cells beyond the gates set for determining positive My10/TR or My10/FITC staining). The negative control for HLA-DR/PE similarly consisted of add- 
Table I. Multipotential Colony Formation (CFU-GEMM) by Fractions of Human Marrow Cells Obtained by Counterflow Centrifugal Elutriation*

\begin{tabular}{ccr}
\hline Flow rate $^{\ddagger}$ & Day 14 & \multicolumn{1}{c}{ Day 21" } \\
\hline 11 & $2.0 \pm 0.0$ & $0.0 \pm 0.0$ \\
12 & $22.5 \pm 2.0$ & $13.0 \pm 4.2$ \\
14 & $18.5 \pm 10.6$ & $5.5 \pm 0.7$ \\
16 & $7.0 \pm 0.0$ & $1.5 \pm 2.1$ \\
18 & $4.0 \pm 5.7$ & $1.5 \pm 2.1$ \\
20 & $2.0 \pm 1.4$ & $0.5 \pm 0.7$ \\
22 & $1.5 \pm 0.7$ & $0.5 \pm 0.7$ \\
$24-32$ & $1.0 \pm 1.4$ & $0.5 \pm 0.7$ \\
Unfractionated low density & & \\
cells $1 \times 10^{5}$ & $4.5 \pm 2.1$ & $1.5 \pm 0.7$ \\
\hline
\end{tabular}

* Marrow cells or marrow cell fractions were assayed in the presence of $1.0 \mathrm{U} / \mathrm{ml}$ of a partially purified preparation of human urinary erythropoietin ( $57 \mathrm{U} / \mathrm{mg}$ protein, Toyobo Co., Ltd., Osaka, Japan), and $10 \%$ phytohemagglutinin stimulated leukocyte conditioned media.

${ }^{\ddagger}$ Low density marrow cells were injected into a Beckman elutriator system with a standard separation chamber (Beckman Instruments, Inc.). After loading, the flow rate of buffer was maintained at $10 \mathrm{ml} /$ min with a rotor speed of $1,950 \mathrm{rpm}$ and $200 \mathrm{ml}$ of effluent was collected. The flow rate was increased in $2-\mathrm{ml} / \mathrm{min}$ increments and 100 $\mathrm{ml}$ of effluent was collected at each increment until a flow rate of 32 $\mathrm{ml} / \mathrm{min}$ was achieved. The cells in each fraction were then assayed for colony formation.

${ }^{8}$ Colonies were enumerated after $14 \mathrm{~d}$ of incubation.

"Colonies were enumerated after $21 \mathrm{~d}$ of incubation.

' Each point represents the mean \pm 1 SD of duplicate points.

ing $\mathrm{PE}$ conjugated $\mathrm{IgG}_{2 \mathrm{a}}$ myeloma protein to the cells, and the nonspecific background fluorescence was less than $1 \%$ at the gate settings used to determine positive DR/PE staining. Cells were maintained at $4^{\circ} \mathrm{C}$ before and during cell sorting.

Cell sorting. Cells were sorted on a Coulter Epics 753 dye laser flow cytometry system (Coulter Electronics, Hialeah, FL). The methods employed have been previously described (28). All data was collected on a 256 channel three decade log scale. TR was excited by the $590-\mathrm{nm}$ line emitted from a coherent dye laser pumping rhodamine $6 \mathrm{G}$ dye, which was in turn excited by the $488 \mathrm{~nm}$ dye from a dedicated $6 \mathrm{~W}$ argon laser. The FITC and PE were excited using the 488-nm wavelength from a second $6 \mathrm{~W}$ argon laser. Sorting windows were established for three separate parameters: forward light scatter, TR or FITC fluorescence, and PE fluorescence by first selecting (gating) for high density My10 positive cells as previously described (28) and then setting sort gates for low and undetectable densities of MHC class II antigen. After sorting, the recovered cell populations were washed twice and resuspended in media containing 10\% FCS (Hyclone, Logan UT). The purity of sorted cells was determined by reanalyzing aliquots of the sorted subsets on the Coulter Epics 753 immediately after the sort was finished (28). The My $10^{+++} \mathrm{DR}^{+}$cell fraction contained $>90 \%$ My 10 positive cells and $>95 \%$ MHC II positive cells, while the My $10^{+++} \mathrm{DR}^{-}$cell fraction contained $>85 \%$ My10 positive cells and $<5 \%$ MHC class II positive cells.

Complement-dependent cytotoxicity. FR 12-14 cells were first incubated at $4^{\circ} \mathrm{C}$ and at a concentration of $6 \times 10^{6} / \mathrm{ml}$ in $50 \mu \mathrm{IMDM}$ for $45 \mathrm{~min}$ with an equal volume of IMDM and anti-HLA-DR antibody (Becton Dickinson) at a plateau killing concentration in sterile microcentrifuge tubes. Control cells were incubated in a similar fashion with media alone, antibody alone or complement alone. The tubes were then centrifuged at $500 \mathrm{~g}$ for $3 \mathrm{~min}$, the supernate was removed, and the cells resuspended in $100 \mu \mathrm{l}$ solution containing $20 \%$ rabbit complement, and incubated at $37^{\circ} \mathrm{C}$ for $60 \mathrm{~min}$. Cells were next washed thrice in IMDM and assayed for progenitor cell and blast cell derived colonies as previously described. The number of cells plated was determined by cell counts made before treatment with antibody and complement.

Statistical analysis. All results are presented as the mean \pm 1 SD or SEM. Levels of significance for comparison between samples were determined using the $t$ test distribution.

\section{Results}

To obtain populations of marrow cells enriched for primitive hematopoietic progenitors, fractions of LD marrow cells were obtained by counterflow centrifugal elutriation. The ability of each fraction to form CFU-GEMM derived colonies was used preliminarily as an indicator of the presence of primitive progenitor cells. The fraction eluting at a flow rate of $12-14 \mathrm{ml} /$ min constituted $10.2 \pm 1.6 \%$ of LD marrow and provided a 5-fold enrichment for CFU-GEMM derived colonies enumer-

Table II. Effect of 5-FU and 4-HC Pretreatment of Human Marrow Cells on Colony Formation by Hematopoietic Progenitor Cells*

\begin{tabular}{|c|c|c|c|c|c|c|}
\hline \multirow[b]{3}{*}{ Cells assayed } & \multicolumn{6}{|c|}{ Hematopoietic progenitor cells $/ 1 \times 10^{5}$ cells plated } \\
\hline & \multicolumn{2}{|c|}{ CFU-GM } & \multicolumn{2}{|c|}{ BFU-E } & \multicolumn{2}{|c|}{ CFU-GEMM } \\
\hline & Day $14^{\#}$ & Day $21^{H 4}$ & Day 14 & Day 21 & Day 14 & Day 21 \\
\hline $\mathbf{L D B M}^{\ddagger}$ & $114.7 \pm 39.6^{1111}$ & $100.3 \pm 12.9$ & $17.8 \pm 9.5$ & $12.8 \pm 7.1$ & $1.8 \pm 2.3$ & $1.7 \pm 0.5$ \\
\hline 5-FU-LDBM ${ }^{\S}$ & $0.2 \pm 0.5$ & $0.5 \pm 0.6$ & $0.0 \pm 0.0$ & $0.0 \pm 0.0$ & $0.0 \pm 0.0$ & $0.0 \pm 0.0$ \\
\hline FR 12-14" & $220 \pm 72.6$ & $175.2 \pm 39.8$ & $57.0 \pm 49.2$ & $21.2 \pm 13.5$ & $8.0 \pm 6.9$ & $2.8 \pm 2.3$ \\
\hline 5-FU-FR 12-14 & $18.7 \pm 7.4$ & $30.4 \pm 10.4$ & $5.5 \pm 3.3$ & $6.3 \pm 4.2$ & $0.0 \pm 0.0$ & $0.4 \pm 0.6$ \\
\hline 4-HC-FR 12-14** & $56.8 \pm 25.2$ & $41.5 \pm 20.1$ & $0.2 \pm 0.5$ & $0.0 \pm 0.0$ & $0.0 \pm 0.0$ & $0.0 \pm 0.0$ \\
\hline
\end{tabular}

* Cells were assayed in methylcellulose cultures in the presence of $10 \%$ media conditioned by the human bladder cell line 5637 and $1.0 \mathrm{U} / \mathrm{ml}$ of a partially purified preparation of human urinary erythropoietin $\left(57 \mathrm{U} / \mathrm{mg}\right.$ protein, Toyobo Co. Ltd, Osaka, Japan). ${ }^{\ddagger}$ Low density bone marrow cells. ${ }^{8}$ Low density bone marrow pretreated with $25 \mu \mathrm{g} / \mathrm{ml}$ of 5-fluorouracil for 24-36 h. "Low density bone marrow cells were further fractionated by counterflow centrifugal elutriation. Those fractions eluted at 12-14 ml/min were then assayed. 'FR 12-14 were pretreated with $25 \mu \mathrm{g} / \mathrm{ml} \mathrm{5-FU}$ for 24-36 h. ** FR 12-14 were pretreated with $2 \mu \mathrm{g} / \mathrm{ml}$ of $4-\mathrm{HC}$ for $24-36 \mathrm{~h}$. $¥$ Colonies were enumerated after $12 \mathrm{~d}$ of incubation. Colonies were enumerated after $21 \mathrm{~d}$ of incubation. IIII Each point represents the mean \pm SD of duplicate assays performed on at least three separate occasions. 

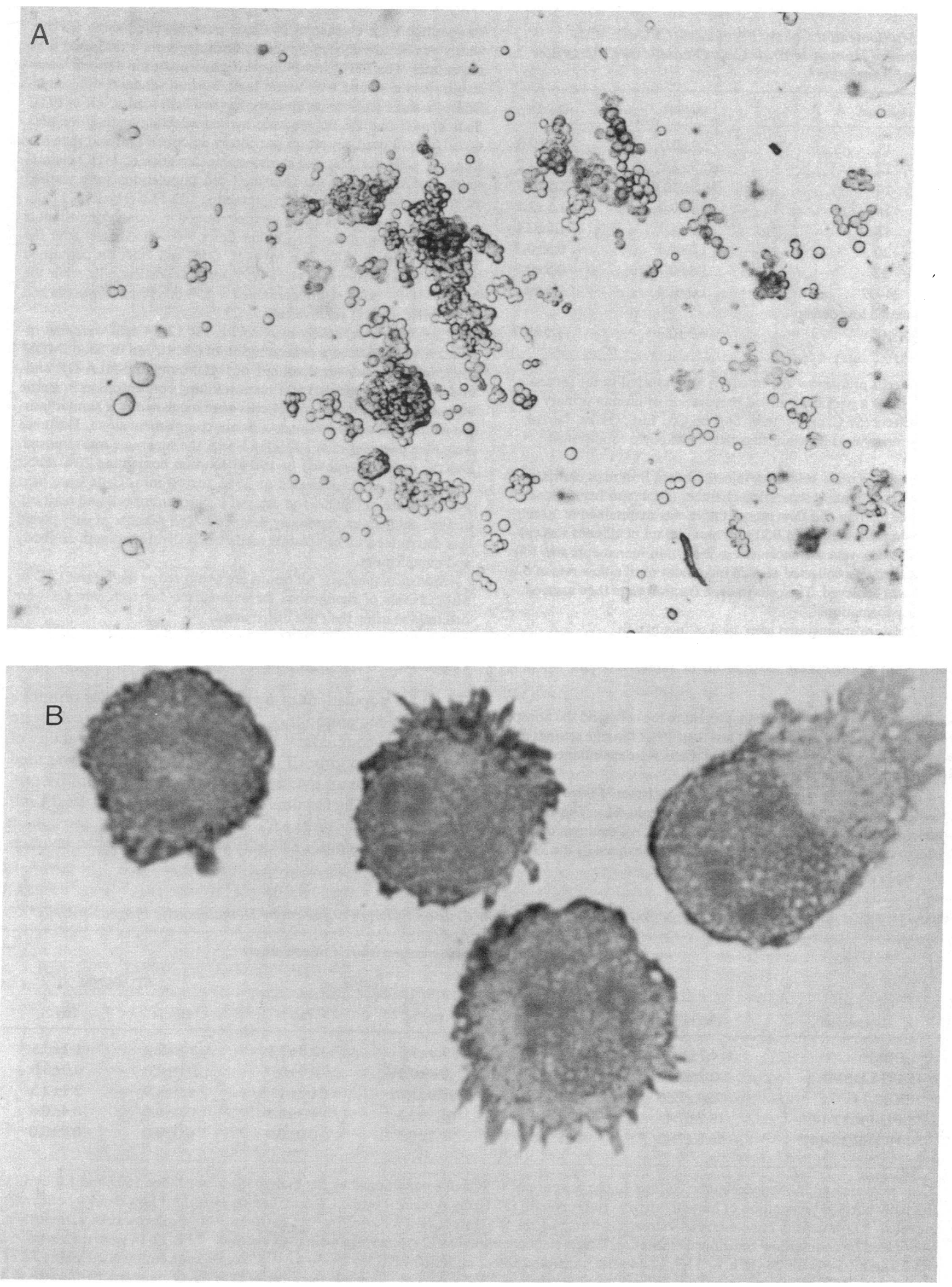
Table III. Morphological Analysis of Cells Constituting Representative Human Blast Cell Containing Colonies

\begin{tabular}{|c|c|c|c|c|c|c|}
\hline \multirow[b]{2}{*}{ Colony } & \multirow[b]{2}{*}{$\begin{array}{l}\text { Total cell count } \\
\text { per } 1 / 2 \text { colony }\end{array}$} & \multicolumn{4}{|c|}{ Percent cell type* } & \multirow[b]{2}{*}{$\begin{array}{l}\text { Segmented } \\
\text { neutrophils }\end{array}$} \\
\hline & & Blasts & Promyelocytes & Myelocytes & Monocytes & \\
\hline $577-5$ & 106 & 50 & 0 & 30 & 8 & 12 \\
\hline $006-1$ & 2,101 & 58 & 18 & 0 & 24 & 0 \\
\hline $007-1$ & 246 & 28 & 62 & 0 & 10 & 0 \\
\hline $007-2$ & 670 & 87 & 11 & 0 & 0 & 2 \\
\hline $007-3$ & 904 & 73 & 2 & 0 & 7 & 18 \\
\hline $007-4$ & 521 & 38 & 9 & 0 & 26 & 27 \\
\hline 010-1 & 874 & 66 & 8 & 0 & 19 & 7 \\
\hline $012-4$ & 313 & 59 & 23 & 0 & 18 & 0 \\
\hline $012-5$ & 302 & 53 & 11 & 0 & 36 & 0 \\
\hline 012-6 & 62 & 90 & 10 & 0 & 0 & 0 \\
\hline Mean \pm SEM & $610 \pm 190$ & $60 \pm 6$ & $15 \pm 6$ & $3 \pm 3$ & $15 \pm 4$ & $7 \pm 3$ \\
\hline
\end{tabular}

* Differential cell counts were performed on Wright-Giemsa stained cytocentrifuge preparations that were lifted from methylcellulose cultures. At least 200 cell differentials were performed or if $1 / 2$ the colony was composed of less than 200 cells all the cells on the cytocentrifuge preparation were classified.

ated on day 14 and a 10 -fold enrichment enumerated after 21 $\mathrm{d}$ of incubation when compared to colony formation by LD cells (Table I). The effect of pretreatment of various fractions of human marrow with 5-FU or 4-HC on the ability of human marrow cells to form hematopoietic colonies in vitro was next evaluated (Table II). In preliminary studies, various doses and times of exposure to these drugs were evaluated to obtain maximal kill of more differentiated progenitor cells to facilitate the detection of more quiescent primitive hematopoietic stem cells. The data from these preliminary studies are not provided for the sake of brevity. Based on these experiments, however, we arrived at the conclusion that a prolonged exposure (24-36 h) to low levels of either 5-FU or 4-HC would be optimal for our purposes. Such treatment with 5-FU resulted in almost total kill of all hematopoietic progenitor cells assayed from low density cells. Yet, when FR 12-14 cells were exposed for $24 \mathrm{~h}$ to $25 \mu \mathrm{g}$ of 5-FU, small numbers of CFU-GEMM derived colonies that were enumerated after $21 \mathrm{~d}$ of incubation survived. It was assumed that these surviving CFU-GEMM represented a more primitive population of CFU-GEMM than normally detected on day 14 . By contrast, 4-HC treatment of FR 12-14 cells led to total kill of CFU-GEMM enumerated at either 14 or $21 \mathrm{~d}$.

The conditions described above were then employed to develop an assay for the human CFU-B1. LD marrows were fractionated by centrifugal elutriation and FR 12-14 cells were exposed to $25 \mu \mathrm{g} / \mathrm{ml}$ of $5-\mathrm{FU}$ for 24 to $36 \mathrm{~h}$. After extensive washing, these cells were then plated in methylcellulose cultures in the presence of $10 \% 5637 \mathrm{CM}$. Between day 21 to day 25 , colonies were visualized on an inverted microscope, lifted individually from culture, and resuspended in medium. Half of each colony was immediately transferred to slides for microscopic examination; those colonies composed of primarily blast cells were replated in methylcellulose containing $10 \%$ $5637 \mathrm{CM}$ and $1 \mathrm{U} / \mathrm{ml}$ Epo for secondary colony formation. The blast cell colonies appeared in vitro as dispersed clusters of round, agranular, nonpigmented cells with no evidence of morphology characteristic of myeloid or erythroid colonies (Fig. $1 a$ ). The cells in these colonies were predominantly agranular blasts with basophilic cytoplasm and multiple, large nucleoli (Fig. $1 b$ ) that demonstrated neither specific nor nonspecific esterase activity; between 28 and $90 \%$ of these colonies were composed of such cells. Monocytes, promyelocytes, and segmented neutrophils frequently represented minority populations in the colonies, which varied in size from 62 to 2,101 cells per one-half colony (Table III).

We detected few CFU-B1 derived colonies when non-drug treated FR 12-14 cells were assayed (Table IV). This was due presumably to the prolific growth of more differentiated progenitor cells that potentially obscured the detection of CFU-B1 derived colonies and the relative rarity of the CFU-B1. By contrast, CFU-B1-derived colonies were repeatedly observed when FR 12-14 cells were exposed to 5-FU or 4-HC before plating (Table IV). A greater number of CFU-B1 were observed when 5-FU-treated cells were assayed than when 4-HC-treated cells were assayed for CFU-B1 derived colony formation $(P<0.01)$.

CFU-B1-derived colony formation was dependent on the presence of $5637 \mathrm{CM}$. No blast cell-containing colonies were detected in the absence of $\mathrm{CM}$, while the addition of Epo alone or in the presence of $5637 \mathrm{CM}$ did not enhance colony formation (Table V). Secondary colonies derived from one-half of the CFU-B1 colonies were individually transferred to slides, stained and examined at day 14. The CFU-B1-derived colonies were able to form single- and multilineage colonies composed of virtually every hematopoietic cellular type. In addition, roughly $20 \%$ of these primary colonies gave rise to secondary blast cell colonies after replating (Tables VI, X). Other colony types, notably those of monocyte-macrophage lineage, infrequently retained a limited replating ability. In such cases, secondary colony formation was always restricted to the single lineage product(s) of the primary colony; none of these colo-

Figure 1. (A) Photomicrograph of a blast cell colony in situ, $\times 40$. (B) Wright-Giemsa stained cytospin preparation of a blast cell containing colony after $21 \mathrm{~d}$ in vitro, $\times 1,000$. 
Table IV. Effect of Pretreatment of Marrow Cells with Chemotherapeutic Agents on Human Blast Cell Containing Colony Formation*

\begin{tabular}{|c|c|}
\hline Cells & CFU-B1 $/ 1 \times 10^{5}$ cells plated \\
\hline FR $12-14^{\ddagger}$ & $0.3 \pm 0.2^{\prime \prime}$ \\
\hline 5-FU-FR $12-14^{8}$ & $2.0 \pm 0.4$ \\
\hline $4-H C-F R$ 12-14" & $1.7 \pm 0.4$ \\
\hline
\end{tabular}

* Cells were assayed in a methylcellulose assay system in the presence of $10 \%$ media conditioned by the human bladder carcinoma cell line 5637. The cultures were incubated for 21-25 d.

${ }^{\ddagger}$ Low density marrow cells were further fractionated by counterflow centrifugal elutriation. Those cells eluted at a velocity of $12-14 \mathrm{ml} /$ min were assayed for CFU-B1.

${ }^{8} \mathrm{FR} 12-14$ cells were pretreated with $25 \mu \mathrm{g} / \mathrm{ml}$ of 5-FU for $24-36 \mathrm{~h}$. " FR 12-14 cells were pretreated with $2 \mu \mathrm{g} / \mathrm{ml}$ of 4-HC for 24-36 h.

' Each point represents the mean \pm SEM of duplicate assays performed on at least three separate occasions.

nies were able to produce multilineage or blast secondary colonies after $21 \mathrm{~d}$ in culture. 5-FU-treated FR 12-14 cells were also plated in the presence of a variety of purified or recombinant growth factors (Table VII). rGM-CSF, rIL-3, and rIL-1 $\alpha$ were each capable alone of promoting CFU-B1-derived colony formation. In contrast, neither CSF-1, rG-CSF, rIL-4, nor rEpo promoted blast cell colony formation.

To immunologically phenotype the CFU-B1, NALT ${ }^{-}$or FR 12-14 marrow cells were incubated with TR or FITC labeled My10 antibody and HLA-DR antibody conjugated with $P E$ and analyzed for subsequent separation of populations of marrow by means of fluorescence activated cell sorting. The distribution of HLA-DR and My10 antigens on these cells is shown in Fig. 2. The viability of cells after sorting was $99 \%$ or greater using trypan blue exclusion. Colony formation by the sorted populations of cells is shown in Table VIII. Data in this table confirm previously published data from our laboratory, which reported that CFU-GM, BFU-E, and CFU-GEMM each express the My10 and HLA-DR antigens (28). Data in

Table V. Effect of Media Conditioned by a Human Bladder Cell Carcinoma Cell Line 5637 and Crude Erythropoietin on Human Blast Cell Containing Colony Formation

\begin{tabular}{lc}
\hline Addition to culture & CFU-B1/1 $\times 10^{5}$ cells plated \\
\hline None & $0.0 \pm 0.0^{\ddagger}$ \\
$5637 \mathrm{CM}^{\S}$ & $2.0 \pm 0.5$ \\
$\mathrm{Epo}^{2}$ & $0.0 \pm 0.0$ \\
$5637 \mathrm{CM}+$ Epo & $2.0 \pm 0.3$
\end{tabular}

\footnotetext{
* Low density marrow cells were further fractionated by counterflow centrifugal elutriation and eluted at $12-14 \mathrm{ml} / \mathrm{min}$. These cells were expanded to $25 \mu \mathrm{g} / \mathrm{ml}$ of $5-\mathrm{FU}$ and then plated in a methycellulose assay system.

${ }^{\ddagger}$ Each point represents the mean \pm SEM of duplicate assays performed on at least five separate occasions.

$\$ 10 \%$ media conditioned for $7 \mathrm{~d}$ by the human bladder cell carcinoma cell line 5637 .

" $1.0 \mathrm{U} / \mathrm{ml}$ of a partially purified preparation of human urinary erythropoietin ( $57 \mathrm{U} / \mathrm{ml}$, Toyobo Co., Ltd.).
}

Table VIII clearly show that the human CFU-B1 is $\mathrm{My} \mathrm{O}^{+++}$ but that the CFU-B1 is different from the other hematopoietic progenitor cells assayed in that it is HLA-DR-. It is also important to note a marked enrichment for CFU-B1 that has been achieved with cell sorting. In these studies $0.2 \%$ of the $\mathrm{My} 10^{+++} / \mathrm{DR}^{-}$were CFU-B1, which represents a 100 -fold enrichment over that achieved with density centrifugation and counterflow centrifugal elutriation coupled with drug treatment. Complement-dependent cytotoxicity was utilized as an alternate methodology to eliminate HLA-DR positive cells in elutriated marrow. This process greatly diminished colony formation by CFU-GM, BFU-E, and CFU-GEMM but not CFU-B1 (Table IX).

A linear response relationship between the number of $\mathrm{My} 10^{+++} \mathrm{DR}^{-}$cells plated and blast cell colonies enumerated was observed when $5 \times 10^{2}$ to $2 \times 10^{3} \mathrm{cells} / \mathrm{ml}$ were assayed (Fig. 3). At higher cell densities, the ability to detect and isolate CFU-B1-derived colonies among other hematopoietic types was obscured and possibly accounts for the plateau levels reached. When $10^{2}$ cells $/ \mathrm{ml}$ were plated, a few (mean $=2.8$ ) monocyte-macrophage but no CFU-B1 derived colonies were observed.

Analysis of antibody/fluorochrome stained NALT $^{-}$cells from multiple donors indicated the presence of a subpopulation of 2-4\% My10 ${ }^{+++} \mathrm{DR}^{-}$cells. When FR 12-14 cells were identically prepared for sorting, $5-14 \%$ were found to be My $10^{+++} \mathrm{DR}^{-}$, demonstrating a higher frequency of this immunological phenotype in the elutriated marrow. $\mathrm{My} 10^{+++} \mathrm{DR}^{-}$cells from either source generated blast cell colonies in vitro.

To be certain that the blast cell colonies assayed from $\mathrm{My} 10^{+++} \mathrm{DR}^{-}$marrow cells had similar behavior to those colonies that were detected after 5-FU treatment, their dependence on the addition of hematopoietic growth factors (Table X), their colony size and morphology (Table XI), and their capacity to form secondary colonies (Table XII) was determined. It can be observed that $\mathrm{My}^{10^{+++}} \mathrm{DR}^{-}$cells, like 5-FU-treated marrow, formed no blast cell colonies in the absence of a source of hematopoietic growth factors. $\mathrm{My} 10^{+++} \mathrm{DR}^{-}$cells formed these colonies in the presence of $5637 \mathrm{CM}$ or recombinant IL-3, but not IL- $1 \alpha$ or IL-4. The behavior of the My $10^{+++} \mathrm{DR}^{-}$cells differed only in the inability of IL-1 $\alpha$ to support blast cell colony formation. The ability of individual blast cell colonies cloned from $\mathrm{My} 10^{+++} \mathrm{DR}^{-}$cells to form secondary colonies in response to $5637 \mathrm{CM}$ and erythropoietin appears to be identical to that of blast cell colonies cloned from 5-FU treated marrow. Blast colonies were able to form secondary blast cell colonies and also multilineage and single lineage progenitor cell-derived colonies.

\section{Discussion}

An in vitro assay system with which to examine the biological characteristics of human pluripotent hematopoietic stem cells that have a capacity for self-renewal and to differentiate along multiple cellular lines has been a long-term goal of a number of groups working in the field of hematopoiesis. Recently, a great deal of progress has been achieved toward accomplishing this objective. Initially, Nakahata and Ogawa described such an assay system using human umbilical cord blood as a source of cells (3). More recently, Rowley and co-workers (4), Leary and Ogawa (5), and Gordon and co-workers (6) have each 


\begin{tabular}{|c|c|c|c|c|c|c|c|c|c|c|c|}
\hline \multirow[b]{2}{*}{ Colony No. } & \multicolumn{11}{|c|}{ No. of secondary colonies per $1 / 2$ blast cell colony } \\
\hline & $\mathbf{B 1}^{*}$ & $\mathbf{M}^{\mathbf{b}}$ & $\mathbf{G}^{\mathbf{c}}$ & $\mathbf{G M}^{\mathbf{d}}$ & GEMM $^{e}$ & $E^{f}$ & GEM $^{2}$ & $\mathbf{G M}^{\mathbf{b}}$ & $\operatorname{Eos}^{i}$ & $\mathbf{M K}^{\mathbf{j}}$ & MKE $^{\mathbf{k}}$ \\
\hline $577-4$ & 1 & 6 & - & 6 & - & - & - & - & - & - & - \\
\hline $577-5$ & - & 4 & - & 3 & 3 & - & - & - & - & - & - \\
\hline $577-6$ & - & - & - & 3 & 3 & - & - & - & - & - & - \\
\hline $612-1$ & - & 2 & 3 & 9 & - & - & - & - & 3 & - & - \\
\hline $612-2$ & 1 & - & - & 22 & 1 & - & - & - & - & - & - \\
\hline $006-1$ & 2 & - & - & 16 & - & - & - & - & - & - & - \\
\hline $007-1$ & - & 1 & 3 & 26 & 1 & - & 1 & - & - & - & - \\
\hline $007-2$ & - & - & 1 & 4 & 1 & 1 & 1 & 4 & 1 & - & - \\
\hline $007-3$ & - & 6 & 1 & 18 & - & - & - & 2 & - & - & - \\
\hline $007-5$ & - & 5 & - & 5 & - & - & 1 & - & - & - & 4 \\
\hline $010-1$ & 2 & 11 & 1 & 14 & - & - & - & - & - & - & - \\
\hline $012-2$ & - & 1 & - & 1 & 1 & - & - & - & 1 & - & - \\
\hline $012-3$ & - & 2 & - & 1 & - & - & - & - & 1 & - & - \\
\hline $012-4$ & - & 8 & - & 1 & - & 1 & 1 & - & - & - & - \\
\hline $012-6$ & - & 16 & - & - & - & 1 & 1 & 1 & - & - & - \\
\hline $012-10$ & 1 & 11 & - & - & - & - & - & - & - & - & - \\
\hline $012-11$ & - & 6 & - & - & - & - & - & - & 1 & 1 & - \\
\hline 019-1 & - & - & - & 4 & 3 & - & - & - & - & - & - \\
\hline
\end{tabular}

* Blast cell colonies were derived from assays of low density marrow cells that were further enriched for marrow cells by centrifugal elutriation. These cells were then exposed to 5-FU at a dose of $25 \mu \mathrm{g} / \mathrm{ml}$ for 24-36 h and plated in the presence of $5637 \mathrm{CM}$. After 21-25 d of incubation, the blast cell colonies were replated into cultures containing $5637 \mathrm{CM}$ and Epo and incubated for an additional $14-16 \mathrm{~d}$. ${ }^{\mathrm{a}} \mathrm{Blast}$ cell; ${ }^{\mathrm{b}}$ macrophage; ${ }^{\mathrm{c}}$ granulocyte; ${ }^{\mathrm{d}}$ granulocyte-macrophage; ${ }^{\mathrm{e}}$ granulocyte, erythroid, macrophage, megakaryocyte; ${ }^{\mathrm{f}}$ erythropoietic burst; ${ }^{\mathbf{8}}$ granulocyte, erythroid, macrophage; ${ }^{\mathrm{h}}$ granulocyte, megakaryocyte; ${ }^{\mathrm{i}}$ eosinophil; ${ }^{\mathrm{j}}$ megakaryocyte; ${ }^{\mathrm{k}}$ megakaryocyte, erythroid.

Table VII. Effect of Recombinant or Purified Hematopoietic Growth Factors on Human Blast Cell Containing Colony Formation

\begin{tabular}{lc}
\hline Additions to culture & CFU-B1/1 $\times 10^{5}$ cells plated* \\
\hline None & $0.0 \pm 0.0$ \\
CSF-1 $^{\ddagger}$ & $0.0 \pm 0.0$ \\
rEpo $^{\S}$ & $0.0 \pm 0.0$ \\
rG-CSF" & $0.0 \pm 0.0$ \\
rGM-CSF & $0.8 \pm 0.2$ \\
rIL-3** & $1.5 \pm 0.3$ \\
rIL-1 $\alpha^{\ddagger \ddagger}$ & $1.8 \pm 0.2$ \\
rIL-4\$ & $0.0 \pm 0.0$
\end{tabular}

\footnotetext{
* Each point represents the mean \pm 1 SD of duplicate studies performed on three different occasions.

$\$ 100 \mathrm{U} / \mathrm{ml}$ of purified human macrophage colony stimulating factor (CSF-1) with a specific activity of $10 \mathrm{U} / \mathrm{mg}$ protein (gift of Dr. Peter Ralph, Cetus Corp.).

$\$ 1.0 \mathrm{U} / \mathrm{ml}$ of recombinant erythropoietin with a specific activity of 70,000-80,000 U/mg (AmGen Biologicals).

" $100 \mathrm{U} / \mathrm{ml}$ of recombinant granulocyte colony stimulating factor with a specific activity of $1 \times 10^{8} \mathrm{U} / \mathrm{mg}$.

$100 \mathrm{U} / \mathrm{ml}$ of recombinant human granulocyte-macrophage colony stimulating factor with a specific activity of $5 \times 10^{7} \mathrm{CFU}-\mathrm{GM} / \mathrm{mg}$ protein (Genzyme Corp., Boston, MA).

** $300 \mathrm{U} / \mathrm{ml}$ of recombinant human interleukin 3 with a specific activity of $10^{8} \mathrm{CFU}-\mathrm{GEMM} / \mathrm{mg}$ protein.

\#50 $\mathrm{U} / \mathrm{ml}$ recombinant human interleukin $1 \alpha$ with a specific activity of $10^{9} \mathrm{U} / \mathrm{mg}$ protein (gift of Dr. Peter LoMedico, Hoffman-LaRoche, Nutley, NJ) or recombinant interleukin $1 \alpha$ with a specific activity of $10^{8} \mathrm{U} / \mathrm{mg}$ protein.

$\$ 100 \mathrm{U} / \mathrm{ml}$ of recombinant human interleukin 4 with a specific activity of $10^{8}$ proliferation units of human tonsillar $B$ cells $/ \mathrm{mg}$ protein.
}

described systems with which to detect these primitive hematopoietic progenitor cells in human marrow. In the present report, we have concentrated on determining the sensitivity of these cells to chemotherapeutic agents, analyzing the immunological phenotype of the CFU-B1, and further defining the dependence of these cells on hematopoietic regulatory molecules.

A number of groups have demonstrated that a population of primitive hematopoietic stem cells is capable of surviving either in vitro or in vivo exposure to chemotherapeutic agents such as 5-FU, 4-HC, and hydroxyurea $(29,30,34,35)$. This chemoselection was successfully exploited in the present studies in order to eliminate overgrowth of colonies derived from more differentiated progenitor cells. The apparent scarcity of CFU-B1-derived colonies in non-drug-treated FR 12-14 should not be interpreted as a reflection of the absence of these cells from these fractions, but rather to their relative rarity and to the difficulty of isolating CFU-B1 derived colonies among other hematopoietic colonies present in the culture dish. The detection of CFU-B1 in a My10 ${ }^{+++}$population of cells that are not drug treated confirms the finding of Leary and Ogawa (5) that the CFU-B1 is My10 positive and emphasizes the importance of using enriched marrow populations with which to assay for CFU-B1. The rarity of these cells in human marrow necessitates the use of either cell sorting, panning, or purging of more differentiated progenitors if one is to detect the CFU-B1 using presently available in vitro assay systems.

It is important to note that drug treatment of cells was exploited to facilitate the detection of CFU-B1 by preferentially killing more committed progenitors. It cannot be assumed that all or even a majority of CFU-B1 survive treatment; the enrichment effected by 5-FU or 4-HC exposure is 


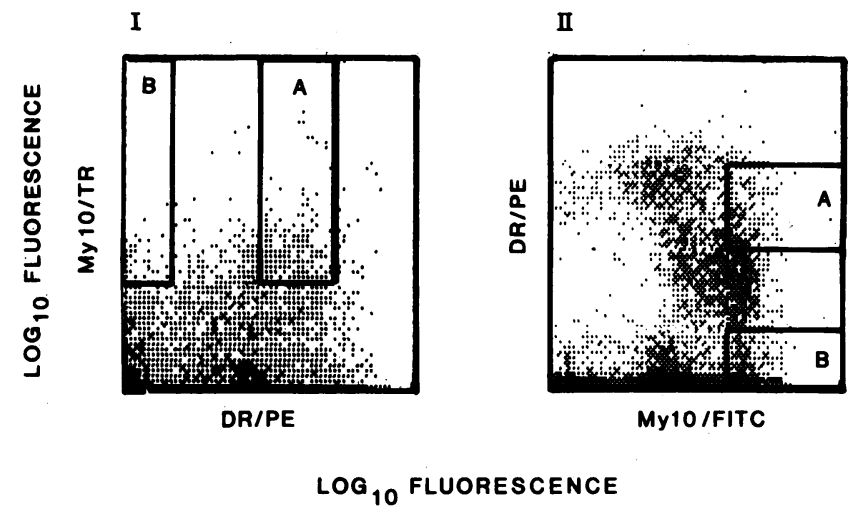

Figure 2. Representative analyses of the density distributions (as determined by immunofluorescence) of HPCA-1 (My10) and HLA-DR antigens on I NALT ${ }^{-}$cells and II FR 12-14 cells. My10 high density cells were sorted in order to isolate populations of cells with low $(A)$ and undetectable $(B)$ densities of MHC class II antigens. Gated twoparameter fluorescence histograms of PE labeled DR and TR and FITC labeled My10 antigen are shown.

merely operational and can not be used to quantitate the CFU-B1 in marrow.

The survival of CFU-B1 after 4-HC treatment has clinical importance. 4-HC has been used to purge marrows of neoplastic cells prior to autologous transplantation for acute nonlymphocytic leukemia (36). Such 4-HC purged marrow following transplantation is capable of engraftment and initiation of sustained hematopoiesis. Since the CFU-B1 appears not to be affected by 4-HC it is possible that this cell or some closely related cell is responsible for marrow engraftment following such transplants. In support of this hypothesis, Siena et al. (37) and Winton and Colenda (38) have shown that 4-HC is extremely toxic to CFU-GEMM and BFU-E yet is capable of initiating in vitro long-term hematopoiesis, suggesting that the cells surviving 4-HC are responsible for marrow repopulation. BFU-E and CFU-GEMM have not proven to be suitable for predicting stem cell survival after 4-HC treatment in vitro (37), while the logarithm of the CFU-GM content of treated grafts has recently been shown to be linearly correlated with time to recovery of peripheral leukocyte counts following autologous transplantation. The data presented in this report suggest that the CFU-B1 assay might also be useful for this purpose. The resistance of CFU-B1 to 4-HC is in agreement with published reports by two other groups $(4,39,40)$.

Table VIII. Hematopoietic Colony Formation by Sorted Marrow Cells

\begin{tabular}{ccccc}
\hline & \multicolumn{4}{c}{ Hematopoietic progenitor cells assayed $/ 1 \times 10^{3}$ cells plated } \\
\cline { 2 - 5 } Cells & CFU-GM & \multicolumn{1}{c}{ BFU-E } & CFU-GEMM & CFU-B1 \\
\hline${\text { My10 } 10^{++} \text {DR }^{-}}^{*}$ & $14.7 \pm 4.3^{\ddagger}$ & $7.7 \pm 3.4$ & $0.5 \pm 0.3$ & $2.2 \pm 0.4$ \\
My10 $^{++}$DR $^{+}$ & $75.5 \pm 3.9$ & $31.0 \pm 2.4$ & $4.0 \pm 1.4$ & $0.0 \pm 0.0$ \\
\hline
\end{tabular}

* Cells were assayed in the presence of $10 \% 5637$ conditioned media and $1.0 \mathrm{U}$ of human urinary erythropoietin $(57 \mathrm{U} / \mathrm{mg}$ protein).

${ }^{\ddagger}$ Each point represents the mean \pm SEM of quadruplicate points from two individual studies.
Table IX. Effect of Complement-dependent Cytotoxic Depletion of HLA-DR Positive Cells on Hematopoietic Colony Formation

\begin{tabular}{lcccc}
\hline & \multicolumn{4}{c}{ Hematopoietic progenitor cells assayed/1 $\times 10^{5}$ cells plated } \\
\cline { 2 - 5 } \multicolumn{1}{c}{ Cells } & CFU-GM $^{*}$ & BFU-E & CFU-GEMM & CFU-B1 \\
\hline Media & $53.8 \pm 6.5$ & $46.3 \pm 2.1$ & $5.3 \pm 1.2$ & $1.0 \pm 0.0$ \\
$\begin{array}{l}\text { Anti-HLA-DR } \\
\text { Rabbit C' }\end{array}$ & $52.3 \pm 9.0$ & $41.5 \pm 6.7$ & $6.5 \pm 1.3$ & NA $^{8}$ \\
$\begin{array}{l}\text { Anti-HLA-DR } \\
\quad \text { rabbit C' }\end{array}$ & $51.3 \pm 4.0$ & $41.3 \pm 4.4$ & $8.3 \pm 4.5$ & NA \\
& $17.3 \pm 2.2$ & $14.8 \pm 1.2$ & $0.5 \pm 0.3$ & $1.0 \pm 0.4$
\end{tabular}

* FR 12-14 cells were assayed in the presence of $10 \% 5637$ conditioned media and $1.0 \mathrm{U}$ of human urinary erythropoietin $(57 \mathrm{U} / \mathrm{mg}$ protein).

₹ Each point represents the mean \pm 1 SEM of duplicate points from two studies.

Not assayed.

Information has been presented demonstrating that the majority of normal human bone marrow CFU-GM, BFU-E and CFU-GEMM express determinants recognized by both HLA-DR and My10 antibodies (14, 15, 28). By using combinations of HLA-DR and My10 antibodies and two-color fluorescence activated cell sorting for isolation of hematopoietic progenitor cells differing in the density expression of HLA-DR and My10 antigens, it has been possible to highly enrich for these cells with some fractions having a total cloning efficiency for CFU-GM, BFU-E, and CFU-GEMM of up to $47 \%$ (28). We have used similar methodology to obtain enriched populations of CFU-B1. The somewhat surprising finding is the localization of the CFU-B1 to an HLA-DR negative population of cells. Hematopoietic cells thought to be more primitive than previously recognized progenitor cells have been shown to be capable of sustaining long term marrow cultures in vitro and to be HLA-DR positive (41). The HLA-DR status of the CFU-B1 reported here has been confirmed using antibody mediated complement dependent cytotoxicity. Preliminary studies in our laboratory using sorted cell populations have demonstrated that $\mathrm{My} \mathrm{O}^{+++} \mathrm{DR}^{-}$cells are capable of sustaining hematopoiesis to a far greater extent than $\mathrm{My}^{10^{+++}} \mathrm{DR}^{+}$ cells in long-term culture for at least $6 \mathrm{wk}$ (unpublished observation). These findings are in agreement with studies by Moore et al. (42) and Keating et al. (43) who used continuous bone marrow cultures to show that human bone marrow cells necessary for generation of long-term cultures were HLA-DR negative. These preliminary data indicate that the cell respon-

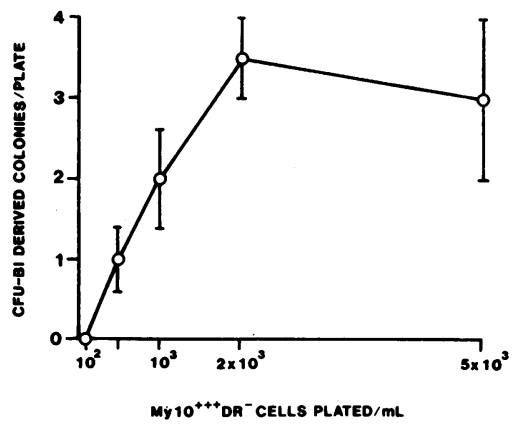

Figure 3. Cell density titration of $\mathrm{MylO}^{+++}$ $\mathrm{DR}^{-}$cells assayed for CFU-B1-derived colonies after $21 \mathrm{~d}$ in culture. Data points indicate the mean \pm SEM of duplicate assays performed on two separate donors. 
Table X. Effect of 5637 Conditioned Media or Recombinant Growth Factors on Human Blast Cell Containing Colony Formation by $\mathrm{MylO}^{+++} \mathrm{DR} \mathrm{R}^{-}$Cells

\begin{tabular}{lc}
\hline Additions to culture & CFU-B1/1 $\times 10^{3}$ cells plated \\
\hline None & $0.0 \pm 0.0$ \\
$5637 \mathrm{CM}^{\ddagger}$ & $1.8 \pm 0.3$ \\
rIL-1 $\alpha^{\S}$ & $0.0 \pm 0.0$ \\
rIL-3" & $1.3 \pm 1.0$ \\
rIL-4 & $0.0 \pm 0.0$
\end{tabular}

* Each point represents the mean \pm 1 SEM of duplicate studies performed on four different occasions.

$\ddagger 10 \%$ media conditioned for $7 \mathrm{~d}$ by the human bladder cell carcinoma line 5637.

$\$ 100 \mathrm{U} / \mathrm{ml}$ recombinant human interleukin $1 \alpha$ with a specific activity of $10^{9} \mathrm{U} / \mathrm{mg}$ protein (gift of Dr. Peter LoMedico) or recombinant interleukin $1 \alpha$ with a specific activity of $10^{8} \mathrm{U} / \mathrm{mg}$ protein.

" $100 \mathrm{U} / \mathrm{ml}$ recombinant human interleukin 3 with a specific activity of $10^{8} \mathrm{CFU}-\mathrm{GEMM} / \mathrm{mg}$ protein.

$100 \mathrm{U} / \mathrm{ml}$ recombinant human interleukin 4 with a specific activity of $10^{8}$ human tonsillar $B$ cell $\mathrm{U} / \mathrm{mg}$ protein.

sible for sustaining long-term hematopoiesis in vitro and that responsible for generating blast cell colonies in vitro might be closely related.

The $\mathrm{My} 10^{+++} \mathrm{DR}^{-}$population of cells could be cultured at $5 \times 10^{2}$ to $2 \times 10^{3}$ cells $/ \mathrm{ml}$ while maintaining qualitatively normal colony growth and linear replating characteristics. At higher cellular densities, total colonies overlapped and were difficult to accurately isolate; when these cells were plated at $10^{2} / \mathrm{ml}$, blast cell colony growth was nondetectable. Similar linear responses at low plating concentrations of highly purified fetal hematopoietic progenitors has been described by Emerson and co-workers (23) when assaying for other hematopoietic colony types.

A large amount of information has been accumulated to show that the process of blood formation is sustained throughout life by a number of hematopoietic growth factors, collectively known as colony-stimulating factors (CSFs) (7-9). The availability of the human CFU-B1 assay has allowed us to determine its dependence on the addition of exogenous growth factors. Our findings suggest that even these primitive hematopoietic stem cells are in vitro dependent on the addition of exogenous CSFs. No CFU-B1 were assayable in the absence of conditioned media or purified hematopoietic regulatory molecules. CFU-B1-derived colony formation was observed after the addition of $5637 \mathrm{CM}$ to the culture mixture. This particular cell line is known to constitutively produce CSAs for myeloid and multipotential progenitors, while H-1, GM-CSF, and G-CSF have each been purified from the conditioned media of this cell line $(44,45)$. Addition of Epo to 5637 did not further favor CFU-B1 derived colony formation (Table V). This information emphasizes the distinct differences between the CFU-B1 and CFU-GEMM $(12,32)$. Four relatively lineage specific factors, rG-CSF, rEpo, rIL-4, and purified CSF-1 did not promote CFU-B1 derived colony formation at any concentration, suggesting that the ability of hematopoietic cells to respond to such factors is acquired at a much more distant step along the differentiation pathway than that at which the CFU-B1 resides.

Hemopoietin-1 (H-1), previously termed synergistic factor, was first detected by its ability to induce stem cells to become responsive to other hematopoietic growth factors (46-48). H-1 has been shown to be identical to interleukin $1 \alpha(47,48)$. It has recently been reported that $\mathrm{H}-1$ activity as identified by an in vitro assay of the ability of $5637 \mathrm{CM}$ to promote high proliferative capacity colony formation can be completely neutralized by an antibody to IL-1 $\alpha(47,50)$. In the original description of the biological properties of $\mathrm{H}-1$ by Stanley and co-workers, the addition of this growth factor alone did not lead to the appearance of hematopoietic colonies, but acted synergistically with CSF-1 or IL-3 $(46,49)$. The promotion of CFU-B1 derived colony formation by rIL- $1 \alpha$ alone by 5 -FU treated marrow but not by $\mathrm{My} \mathrm{O}^{+++} \mathrm{DR}^{-}$is at first confusing since the blast cell colonies generated from either cellular source had identical biological characteristics. An explanation for this difference might be in the recent observation by a number of groups that IL- $\alpha$ acts by promoting the release of cytokines from a variety of marrow accessory cells (51-57). Since the 5FU-treated marrow fraction is a rather heterogenous population the IL- $1 \alpha$

Table XI. Morphological Analysis of Representative Human Blast Cell Containing Colonies Derived from My10 ${ }^{+++} \mathrm{DR} \mathrm{R}^{-}$Cells

\begin{tabular}{|c|c|c|c|c|c|c|}
\hline \multirow[b]{2}{*}{ Colony } & \multirow{2}{*}{$\begin{array}{l}\text { Total cell count } \\
\text { per } 1 / 2 \text { colony }\end{array}$} & \multicolumn{4}{|c|}{ Percent cell type* } & \multirow{2}{*}{$\begin{array}{l}\text { Segmented } \\
\text { neutrophils }\end{array}$} \\
\hline & & Blasts & Promyelocytes & Myelocytes & Monocytes & \\
\hline $44 \mathrm{Gl}$ & 88 & 59 & 7 & 28 & 6 & 0 \\
\hline 44G2 & 89 & 90 & 2 & 0 & 8 & 0 \\
\hline 44G3 & 84 & 54 & 13 & 12 & 16 & 5 \\
\hline 49B1 & 709 & 64 & 12 & 18 & 4 & 2 \\
\hline 49D2 & 176 & 76 & 10 & 0 & 14 & 0 \\
\hline 49D3 & 782 & 85 & 9 & 6 & 0 & 0 \\
\hline 49D5 & 2,211 & 90 & 7 & 1 & 2 & 0 \\
\hline 49D11 & 382 & 68 & 10 & 3 & 5 & 14 \\
\hline Mean \pm SEM & $565 \pm 255$ & $73 \pm 5$ & $9 \pm 1$ & $9 \pm 4$ & $7 \pm 2$ & $3 \pm 2$ \\
\hline
\end{tabular}

* Differential cell counts were performed on Wright-Giemsa-stained cytocentrifuge preparations that were lifted from methylcellulose cultures. At least 200 cell differentials were performed or if $1 / 2$ the colony was composed of less than 200 cells all the cells on the cytocentrifuge preparations were classified. 
Table XII. Replating Studies of Human Blast Cell Colonies Derived from $\mathrm{My}^{10^{+++}} \mathrm{DR}^{-}$Cells*

\begin{tabular}{lccccccc}
\hline & \multicolumn{7}{c}{ Number of secondary colonies per $1 / 2$ blast cell colony } \\
\cline { 2 - 7 } Colony No. & B1 $^{\circ}$ & $\mathrm{M}^{\mathrm{b}}$ & $\mathrm{G}^{\mathrm{c}}$ & GM $^{\mathrm{d}}$ & GEMM $^{\bullet}$ & $\mathrm{E}^{\mathrm{f}}$ & GEM $^{\circ}$ \\
\hline 44G1 & 2 & 5 & 2 & 4 & - & 1 & - \\
44G2 & - & - & - & - & - & 3 & - \\
44G3 & - & 3 & 1 & 2 & - & - & - \\
49B1 & - & 34 & - & - & - & 53 & 5 \\
49D2 & 1 & 39 & 1 & 2 & - & - & 1 \\
49D3 & - & 18 & - & - & - & 7 & - \\
49D5 & - & - & - & - & 1 & 4 & - \\
49D11 & - & 13 & 2 & 3 & - & - & - \\
\hline
\end{tabular}

\begin{abstract}
* Blast cell colonies were derived from assays of low density marrow cells that were further enriched for marrow cells by centrifugal elutriation. These cells were then sorted and the $\mathrm{My} \mathrm{O}^{+++} \mathrm{DR}^{-}$fraction plated in the presence of $5637 \mathrm{CM}$. After 21-25 d of incubation, the blast cell colonies were replated into cultures containing $5637 \mathrm{CM}$ and incubated for an additional 14-16 d.

a Blast cell; ${ }^{\mathrm{b}}$ macrophage; ${ }^{\mathrm{c}}$ granulocyte; ${ }^{\mathrm{d}}$ granulocyte-macrophage; ${ }^{\text {e }}$ granulocyte, erythroid, macrophage, megakaryocyte; ${ }^{\mathrm{f}}$ erythropoietic burst; ${ }^{8}$ granulocyte, erythroid, macrophage.
\end{abstract}

effect observed is presumably due to stimulated release of growth factor(s) from marrow auxillary cells rather than an initial independent direct effect on the CFU-B1. These accessory cell cytokines then would promote CFU-B1 derived colony formation, perhaps in part by synergizing with IL $-1 \alpha$. The inability to observe a similar phenomenon when assaying the $\mathrm{My} 10^{+++} \mathrm{DR}^{-}$cells, then, would be due to an absence of its accessory cell population from this highly select cell population, thus depriving the cells of the accessory cell-derived cytokine necessary for blast cell colony formation. These data suggest that IL- $1 \alpha$ might have potential therapeutic use as a growth factor to promote marrow repopulation following chemotherapy or radiation therapy (58).

The availability of assays for more primitive human hematopoietic stem cells provides investigators with a new cell biological tool with which to investigate normal human blood cell formation. In addition, new information concerning bone marrow failure states and clonal hematopoietic neoplasms in man will likely to be forthcoming with the use of the CFU-B1 assay.

\section{Acknowledgments}

We wish to thank Stephanie Moore for excellent secretarial support during the preparation of this manuscript.

Supported in part by grant CA-34841 from the National Institutes of Health.

\section{References}

1. Nakahata, T., and M. Ogawa. 1982. Identification in culture of a new class of hemopoietic colony forming units with extreme capability to self-renew and generate multipotential colonies. Proc. Natl. Acad. Sci. USA. 79:3843-3847.

2. Keller, G. M., and R. A. Phillips. 1982. Detection in vitro of a unique, multipotent hemopoietic progenitor. J. Cell. Physiol. Suppl. 1:31-36.
3. Nakahata, T., and M. Ogawa. 1982. Hemopoietic colony-forming cells in umbilical cord blood with extensive capability to generate mono and multipotential hemopoietic progenitors. J. Clin. Invest. 70:1324-1328.

4. Rowley, S. D., S. J. Sharkis, C. Hattenburg, and L. L. Sensenbrenner. 1987. Culture from human bone marrow of blast progenitor cells with an extensive proliferative capacity. Blood. 69:804-808.

5. Leary, A. G., and M. Ogawa. 1987. Blast cell colony assay for umbilical cord blood and adult bone marrow progenitors. Blood. 69:953-956.

6. Gordon, M. Y., C. R. Dowding, G. P. Riley, and M. F. Greaves. 1987. Characterization of stroma-dependent blast colony-forming cells in human marrow. J. Cell. Physiol. 130:150-156.

7. Sieff, C. A. 1987. Hematopoietic growth factors. J. Clin. Invest. 79:1549-1557.

8. Metcalf, D. 1985 . The granulocyte-macrophage colony stimulating factors. Science (Wash. DC). 229:16-22.

9. Clark, S. C., and R. Kamen. 1987. The human hematopoietic colony-stimulating factors. Science (Wash. DC). 236:1229-1237.

10. Humphries, R. K., A. C. Eaves, and C. J. Eaves. 1981. Self-renewal of hemopoietic stem cells during mixed colony formation in vitro. Proc. Natl. Acad. Sci. USA. 78:3629-3633.

11. Johnson, G. R., and D. Metcalf. 1977. Pure and mixed erythroid colony formation in vitro stimulated by spleen conditioned medium with no detectable erythropoietin. Proc. Natl. Acad. Sci. USA. 74:3879-3882.

12. Ash, R. C., R. A. Detrick, and E. D. Zanjani. 1981. Studies of human pluripotential hemopoietic stem cells. Blood. 58:309-316.

13. Morstyn, G., N. A. Nicola, and D. Metcalf. 1980. Purification of hematopoietic progenitor cells from human marrow using a fucosebinding lectin and cell sorting. Blood. 56:798-806.

14. Civin, C. I., L. C. Strauss, C. Brovall, M. J. Fackler, J. F. Schwartz, and J. H. Shaper. 1984. Antigenic analysis of hematopoiesis III. A hematopoietic perogenitor cell surface antigen defined by a monoclonal antibody raised against KG-Ia cells. J. Immunol. 133:157-165.

15. Civin, C. I., M. L. Banguenigo, L. S. Strauss, and M. R. Loken. 1987. Antigenic analysis of hematopoiesis. VI. Flow cytometric characterization of My10-positive progenitor cells in normal human bone marrow. Exp. Hematol. 15:10-17.

16. Bodger, M. P., C. A. Izaguirre, H. A. Blacklock, A. V. Hoffbrand. 1983. Surface antigenic determinants on human pluripotent and unipotent hematopoietic progenitor cells. Blood. 61:1006-1010.

17. Katz, F. E., R. Tindle, D. R. Sutherland, M. F. Greaves. 1985. Identification of a membrane glycoprotein associated with haemopoietic progenitor cells. Leukemia Res. 9:191-198.

18. Andrew, R. G., J. W. Singer, and I. D. Bernstein. 1986. Monoclonal antibody 12-8 recognizes a $115 \mathrm{KD}$ molecule present on both unipotent and multipotent hematopoietic colony forming cells and their precursors. Blood. 67:842-845.

19. Griffin, J. D., K. D. Sabbath, F. Herrmann, P. Larcom, K. Nichols, M. Kornachi, H. Levine, and S. A. Cannistra. Differential expression of HLA-DR antigens in subsets of human CFU-GM. Blood. 66:788-795.

20. Nicola, N. A., D. Metcalf, H. V. Melchner, and A. W. Burgess 1984. Isolation of murine fetal hemopoietic progenitor cells and selective fractionation of various erythroid precursors. Blood. 68:376-384.

21. Williams, D. E., J. E. Straneva, R. N. Shen, and H. E. Broxmeyer. 1987. Purification of murine bone marrow derived granulocyte-macrophage colony forming cells. Exp. Hematol. 15:243-250.

22. Visser, J. W. M., J. G. J. Bauman, A. H. Mulder, J. E. Eliason, A. M. DeLeluw. 1984. Isolation of murine pluripotent hematopoietic stem cells. J. Exp. Med. 59:1576-1590.

23. Emerson, S. G., C. A. Sieff, E. A. Wang, G. G. Wong, S. C. Clark, and D. G. Nathan. 1985. Purification of fetal hematopoietic progenitors and demonstration of recombinant multipotential colony stimulating activity. J. Clin. Invest. 76:1286-1290.

24. Griffin, J. D., R. P. Beveridge, and S. F. Schlossman. 1982. 
Isolation of myeloid progenitor cells from peripheral blood of chronic myelogenous leukemia patients. Blood. 60:30-37.

25. Ferrero, D., H. E. Broxmeyer, G. L. Paglidari, S. Venuta, S. Lange, S. Pessano, and G. Rovera. 1983. Antigenically distinct subpopulations of myeloid progenitor cells (CFU-GM) in human peripheral blood and marrow. Proc. Natl. Acad. Sci. USA. 80:4114-4118.

26. Winchester, R. J., G. D. Ross, C. I. Jarowski, C. Y. Wang, J. Halper, and H. E. Broxmeyer. 1977. Expression of Ia-like antigen molecules on human granulocytes during early phases of differentiation. Proc. Natl. Acad. Sci. USA. 74:4012-4019.

27. Janossy, G., G. E. Francis, D. Capellaro, A. H. Goldstone, and M. F. Greaves. 1978. Cell sorter analysis of leukemia-associated antigens on human myeloid precursors. Nature (Lond.). 276:176-178.

28. Lu, L., D. Walker, H. E. Broxmeyer, R. Hoffman, W. Hu, E. Walker. 1987. Characterization of adult human hematopoietic progenitors highly enriched by two-color sorting with My10 and major histocompatibility class II monoclonal antibodies. J. Immunol. 139:1823-1829.

29. Hodgson, G. S., and T. R. Bradley. 1979. Properties of hematopoietic stem cells surviving 5-fluorouracil treatment: evidence for a pre-CFU-S cell? Nature (Lond.). 281:381-382.

30. VanZant, G. 1984. Studies of hematopoietic stem cells spared by 5-fluorouracil. J. Exp. Med. 159:679-690.

31. Berkow, R. L., J. E. Straneva, E. Bruno, G. S. Beyer, J. S. Burgess, and R. Hoffman. 1984. The isolation of human megakaryocytes by density centrifugation and counterflow centrifugal elutriation. J. Lab Clin. Med. 163:811-818.

32. Fauser, A. A., and H. A. Messner. 1979. Identification of megakaryocytes, macrophages and eosinophils in colonies of human bone marrow containing neutrophilic granulocytes and erythroblasts. Blood. 53:1023-1034.

33. Lu, L., L. M. Pelus, H. E. Broxmeyer, M. A. S. Moore, M. Wachter, D. Walker, and E. Platzer. 1986. Enhancement of the proliferation of human marrow erythroid (BFU-E) progenitor cells by prostaglandin $E$ requires the participation of OKT8-positive $T$ lymphocytes and is associated with the density expression of a major histocompatibility complex class II antigens on BFU-E. Blood. 68:126-133.

34. Korbling, M., A. D. Hess, P. J. Tutschka, H. Kaizer, O. M. Colvin, and G. W. Santos. 1982. 4-hydroperoxycyclophosphamide: a mode for eliminating residual tumor cells and $T$ lymphocytes from the bone marrow graft. Br. J. Haematol. 52:89-96.

35. Rowley, S. D., O. M. Colvin, and R. K. Stuart. 1985. Human multilineage progenitor cell sensitivity to 4-hydroperoxycyclophosphamide. Exp. Hematol. 13:295-298.

36. Kaizer, H., R. K. Stuart, R. Brookmeyer, W. E. Beschorner, H. G. Braine, W. H. Burns, D. J. Fuller, M. Korbling, K. F. Mangan, R. Saral, L. Sensenbrenner, R. K. Shadduck, A. C. Shende, P. J. Tutschka, A. M. Yeager, W. Zinkam, O. M. Colvin, and G. W. Santos. 1985. Autologous bone marrow transplantation in acute leukemia. A phase I study of in vitro treatment of marrow with 4-hydroperoxycyclophosphamide to purge tumor cells. Blood. 65:1504-1510.

37. Siena, S., H. Casto-Malaspina, S. C. Gulati, L. Lu, O. M. Colvin, B. D. Clarkson, R. J. O'Reilly, and M. A. S. Moore. 1985. Effects of in vitro purging with 4-hydroperoxycyclophosphamide on the hematopoietic and microenvironmental elements of human bone marrow. Blood. 65:655-662.

38. Winton, E. F., and K. W. Colonda. 1987. Use of long-term human marrow cells to demonstrate progenitor cell precursors marrow treated with 4-hydroperoxycyclophosphamide. Exp. Hematol. 15:710-714.

39. Rowley, S. D., M. Zuehhlsdorf, H. G. Braine, O. M. Colvin, J. Davis, R. J. Jones, R. Saral, L. L. Sensenbrenner, A. Yeager, and G. W. Santos. CFU-GM content of bone marrow graft correlates with time to hematologic reconstitution following autologous bone marrow transplantation with 4-hydroperoxycyclophosphamide purged bone marrow. Blood. 70:271-275.

40. Gordon, M. Y., J. M. Goldman, and E. C. Gordon-Smith 1985. 4-hydroperoxycyclophosphamide inhibits proliferation by human granulocyte-macrophage colony forming cells (GM-CFC) but spare more primitive progenitor cells. Leukemia Res. 1017-1021.

41. Falkenburg, J. H. F., W. E. Fibbe, H. M. Goselink, J. J. VanRood, and J. Jansen. 1985. Human hematopoietic progenitor cells in long term cultures express HLA-DR antigens and lack HLA-DR antigens. J. Exp. Med. 162:1359-1369.

42. Moore, M. A. S., H. E. Broxmeyer, A. P. C. Sheridan, P. A. Myers, A. Jacobsen, and R. J. Winchester. 1980. Continuous human bone marrow culture: Ia antigen characterization of probable pluripotential stem cells. Blood. 55:682-690.

43. Keating, A., J. Powell, M. Takahashi, and J. W. Singer. 1984. The generation of human long term marrow cells from marrow depleted of Ia (HLA-DR) positive cells. Blood. 64:1159-1162.

44. Jubinsky, P. T., and E. R. Stanley. 1985. Purification of hemopoietin-1, a multilineage hematopoietic growth factor. Proc. Natl. Acad. Sci. USA. 82:2764-2768.

45. Platzer, E., K. Welte, L. Lu, J. Gabrilove, E. Levi, R. Mertelsman, and M. A. S. Moore. 1985. Biological activities of a human pluripotent hemopoietic colony stimulating factor on normal and leukemia cells. J. Exp. Med. 162:1788-1801.

46. Stanley, E. R., A. Bartocci, D. Patinkin, M. Rosendaal, and T. R. Bradley. 1986. Regulation of very primitive, multipotent hemopoietic cells by hemopoietin-1. Cell. 43:667-674.

47. Groopman, J. E. 1987. Hematopoietic growth factors: from methylcellulose to man. Cell. 50:505-506.

48. Mochizuki, D. Y., J. A. Eisenman, P. J. Conlon, and A. Larsen, R. J. Tushinski. 1987. Interleukin $1 \alpha$ regulated hematopoietic activity, a role previously ascribed to hemopoietin 1. Proc. Natl. Acad. Sci. USA. 84:5267-5271.

49. Koike, K., J. N. Ihle, and M. Ogawa. 1986. Declining sensitivity to interleukin 3 of murine multipotential hematopoietic progenitors during their development. Application to a culture system that favors blast cell colony formation. J. Clin. Invest. 77:894-899.

50. Sherr, C. J. 1987. Leukemia and lymphoma 1987. Cell. 48:727-729.

51. Fibbe, W. E., J. VanDamme, A. Billiau, P. J. Voogt, N. Duinkerken, P. M. C. Kluck, and J. H. F. Falkenburg. 1986. Interleukin-1 $\alpha$ (22-K factor) induces release of granulocyte-macrophage colony stimulating activity from human mononuclear phagocytes. Blood. 68:1316-1321.

52. Zucali, J. R., C. A. Dinarello, D. J. Oblon, M. A. Gross, L. Anderson, and R. S. Weiner. 1986. Interleukin $1 \alpha$ stimulates fibroblasts to produce granulocyte-macrophage colony-stimulating activity and prostaglandin $\mathrm{E}_{2}$. J. Clin. Invest. 77:1857-1863.

53. Bagby, G. C., Jr., C. A. Dinarello, P. Wallace, C. Wagner, S. Hefeneider, and E. McCall. 1986. Interleukin $1 \alpha$ stimulates granulocyte-macrophage colony-stimulating activity release by vascular endothelial cells. J. Clin. Invest. 78:1316-1323.

54. Sieff, C. A., S. Tsai, and D. V. Faller. 1987. Interleukin $1 \alpha$ induces cultured human endothelial cell production of granulocytemacrophage colony-stimulating factor. J. Clin. Invest. 79:48-51, 1987.

55. Lovhaug, D., L. M. Pelus, E. M. Nordie, A. Boyum, and M. A. S. Moore. 1986. Monocyte-conditioned medium and interleukin $1 \alpha$ induce granulocyte-macrophage colony-stimulating factor production in the adherent cell layer of murine bone marrow cultures. Exp. Hematol. 14:1037-1042.

56. Rennick, D., G. Yang, L. Gemmell, and F. Lee. 1987. Control of hemopoiesis by a bone marrow stromal cell clone. Lipopolysaccharide-and interleukin-1-inducible production of colony-stimulating factors. Blood. 69:682-691.

57. Broudy, V. C., K. S. Zuckerman, S. Jetmalani, J. H. Fitchen, and G. C. Bagby, Jr. 1986. Monocytes stimulate fibroblastoid bone marrow stromal cells to produce multilineage hematopoietic growth factors. Blood. 68:530-534.

58. Moore, M. A. S., and D. J. Warren. 1987. Synergy of interleukin 1 and granulocyte colony-stimulating factor: In vivo stimulation of stem-cell recovery and hematopoietic regeneration following 5-fluorouracil treatment of mice. Proc. Natl. Acad. Sci. USA. 84:7134-7138. 